\title{
The Corporate State: Historical Prospective on International Industrial Relations
}

\author{
Harry Bleas \\ Victoria University, Australia
}

\begin{abstract}
Since the 1970s transnational corporations have increasingly sought to move business to locations where labour was cheapest. They saw this as an opportunity to maximize profit and reduce tax. The paper compares the experiences of Singapore and Hong Kong, the first wave of countries to open their markets to foreign corporations, with other countries such as Bangladesh and Myanmar which are the latest countries to enter into the 'cheap labour for hire' business. The paper argues that countries that do not have strong government policies face having their country being used for forced labour by unscrupulous corporations and individuals seeking to make huge profits.
\end{abstract}

\section{Introduction}

The creation of the United Nations ('U.N') and International Labour Organization ('ILO') led to the recognition of Universal Human Rights and greater acknowledgement of workers' rights ${ }^{1}$. The United Nations was instrumental in fostering greater economic ties with all signatories' members through conventions and treaties. Many of these conventions and treaties focused on the fostering closer economic ties by creating a uniform legal system such as the UNIDROT model law in contract law so companies could do business in other countries easier ${ }^{2}$. Meanwhile, the ILO to this day has sought to represent the rights of Worker's Rights and ensure that Workers' are treated fairly and humanly. However, in the 1970's the ILO was in conflict with the United States Government over its fights for social justice which resulted in funding for the ILO being cut. It was only reinstated when the ILO promised it would no longer use a Human Rights approach to Worker's Rights and instead it would follow the 'Washington Consensus' ${ }^{3}$. This shift had led to the ILO avoid linking human Rights to Workers Rights even to this day ${ }^{4}$.

The paper will examine how institutions such as the United Nation and International Labour organizations expanded the concept of universal human rights for all. Yet, increasingly economics and profit maximization by transnational corporation is limiting the scope and applicability of these fundamental Human rights. The paper will focus on the issue of 'forced labor' of workers which is

Copyright (C) 2015 Victoria University. This document has been published as part of the Journal of Law and Governance in both online and print formats. Educational and non-profit institutions are granted a non-exclusive licence to utilise this document in whole or in part for personal or classroom use without fee, provided that correct attribution and citation are made and this copyright statement is reproduced. Any other usage is prohibited without the express permission of the publisher. now estimated to be at 21 million worldwide. It will explore how corporations have played the first world against the third world all in the quest for profits maximization. The paper will conclude invariably it is the poor that end up paying the price and unless human rights principles are expanded to all, forced labor will only increase in the future.

\footnotetext{
${ }^{1}$ Herbert Kronke, The UN Sales Convention, The UNIDROIT Contract Principles and the Way Beyond, 452 Journal of Law and Commerce, Vol 2, 451

2 Ibid Beigbeder, Yves (1979). "The United States' Withdrawal from the International Labor Organization". Relations industrielles / Industrial Relations 34 (2): 223-240. doi:10.7202/028959ar.p 451

3 Standing, Guy (2008). "The ILO: An Agency for Globalization?". Development and Change 39 (3): $355-384$. doi: $10.1111 /$ j.1467-7660.2008.00484 x. Retrieved 4 August 2012.

${ }^{4}$ Ibid p 355.
} 


\section{Historical prospective of economic development of first world nations}

After the 1945 the United Nations was created to replace the League of Nations. The purpose of the United Nations was to enshrine universal human rights for all. This was done to avoid the horrors of the second war and the persecution of the Jews and other minorities who were not protected by any laws of a particular nation ${ }^{5}$. In order for a nation to join the United Nation they had to become signatories to the various conventions and treaties which seek to make universal human rights the basis for every citizen of the World. However, the United Nations is an umbrella organization with other sections such as the International Labour Organization, The World Food and The World Health Organization. They have also been instrumental creating treaties and conventions for countries and corporations to business with each other. Such as the UNIDROT model which attempted to make contractual relations easier for business wanting to engage in international trade and commerce ${ }^{6}$. The U.N has been an effective player in protection human rights and helping globalize the world's economy.

However, in order to achieve many of these gains the U.N and ILO has had to exercise great restraint or risk the possibility of alienating certain members. Currently, there are five committee members who are permanent members; these include U.S.A, China, Russia, Britain and France ${ }^{7}$. They provide the bulk of the funding to the U.N activities and as a result exercise and great deal of power because they can veto bills or remove funding all together. In 1975 the ILO allowed a U.S.S.R member to join its board and in addition it sought to make a resolution regarding the plight of Palestinian people. The U.S.A walked out the meeting and send notice revoking their membership to the organization for 1977 time period and they are stated that they would cancel all funding for ILO which was 35 percent of all funding to $\mathrm{ILO}^{8}$. This would have had detrimental effect on the organization from this point onward the ILO moved away from viewing workers' rights through human rights. Instead they were forced to adopt the 'Washington Consensus' which advocates free trade and the expansion of market forces in the domestic economy ${ }^{9}$. The threat to revoke membership and funding has forced the ILO to avoid the thorny issue of human rights and forced labor in the same sentence. Unfortunately, to do otherwise would mean there would be no governing international agency focusing on workers' rights but such restriction on the ILO allowed certain groups and nations to exploit it agreement for their own means.

\section{Corporations Playing the $3^{\text {rd }}$ World Against $1^{\text {st }}$ World}

After the Second World War most countries including as Canada, the U.S.A and Australia experienced a massive economic expansion ${ }^{10}$. In Australia the government had already had introduced wage centralization but they adopted Keynesian economic which advocated the use of trade barrier to protect domestic industries. Australia had a strong union movement and fought successfully to maintain workers' rights and conditions ${ }^{11}$. From 1945 to 1970 the pay and working conditions of Australian increased substantially. Keynesian economics was credited for creating 'Golden Age' for capitalism. However, as a result of the petrol crisis, the gold standard crisis and the emergence of stagflation Keynesian economics was removed in favor of Milton Freedman's theories that governments are over regulated and which believed that the role of governments should avoid involving itself in wage centralization and trade barriers should be removed altogether ${ }^{12}$.

\footnotetext{
${ }^{5}$ Hoopes, Townsend; Brinkley, Douglas (11 July 2000). FDR and the Creation of the U.N. pp. 1-55.. Retrieved 2014-11-13.

${ }^{6}$ Osmańczyk, Edmund Jan (February 2004). Encyclopedia of the United Nations and International Agreements: T to Z.

Taylor \& Francis. p. 2445.

${ }^{7}$ Op cit $n 4$ at 231

${ }^{8}$ Op cit n 5 at 351

${ }^{9}$ Op cit $\mathrm{n} 5$ at 351

${ }^{10}$ Robert Skidelsky (2009). Keynes: The return of the Master. Allen Lane. pp. 116, 126.

${ }^{11}$ Brian McKinley, (1979). A Documentary History of the Australian Labor Movement 1850-1975) pp: 121-125

12 Ibid p 126
} 


\section{The Emergence of the $3^{\text {rd }}$ World}

However, by the late 1960's and 1970's the world witnessed unprecedented economic growth and the emergence of transnational corporations ${ }^{13}$. As the other economics began recover from the destruction of infrastructure during the Second World War, they also began to economically improve their financial situation. Many transnational corporations saw great opportunity to expand their market share in these countries which had not been viewed in the past as being viable. In addition, such countries presented an opportunity to move their business operations as they were cheaper in taxes and wages ${ }^{14}$. Moreover, these countries had laws which restricted trade union militancy. Therefore, unions had a very limited role to play in industrial relations. Transnational corporations saw this as an opportunity to maximize profit and reduce $\operatorname{tax}^{15}$. The paper will use as a case study Singapore and Hong Kong. As they were the first wave of countries to open their markets to foreign corporations and compared this to other countries such as Bangladesh and Myanmar which are the latest countries to enter into the cheap labour for hire business. The paper will argue that countries that do not have do not have a strong government policies face having their country being used for forced labour by unscrupulous corporation and individuals seeking to make huge profits off the back of workers.

\section{First Wave of Industrialization}

In 1961 Singapore joined with Malaysia and formed a union together. By 1965 the economic union between Malaysia and Singapore collapsed. Singapore was officially kicked out of the union and forced to fend for themselves ${ }^{16}$. Singapore was a very small nation state and it was believed that they would not survive without the help of another country. Additionally, Prime Minister Lee Kuan Yew sought to make Singapore a place to do business for transnational corporations to help him turn Singapore into an economic powerhouse ${ }^{17}$.

However, to get their support the Yew Government removed the opposition party which was closely aligned with Works Rights ${ }^{18}$. His government outlawed all trade unions and saw to it that they had virtually no role to play in negotiating workplace pay and conditions. He also reduced the right to freedom of speech. Singapore also has low taxes which is a flat rate of $15 \%$ and no other taxes such as capital gains $\operatorname{tax}^{19}$. Hong Kong was very similar to Singapore in that it is small physically, but Hong Kong remained a part of the English Empire until 1999. It had cheap taxes and limited democratic institutions ${ }^{20}$. Trade unionism had been limited as a result of the 1967 riots where unionist loyal to China caused riots and damaged infrastructure. Outlawed and ban from political life in Hong Kong, it was not until 1990's that the participants who took part in the 1967 riots where allowed to reenter politics. ${ }^{21}$ This situation was highly beneficial for transnational corporations who wanted to maximize their profits and avoid dealing with trade unions.

In the 1960's and1970's the wages of the first world in comparison to the third world was substantial. By the 1980's first world nations realized they could not compete with former third world nation countries on labour $\operatorname{costs}^{22}$. If they did not do something they would lose all of the transnational

13 Klein, Naomi (2008). "3". The Shock Doctrine. Penguin. p. 55.

14 Henry Wai-chung Yeung 2003 Managing Economic (In)security in the GlobalEconomy:Institutional Capacity and Singapore's Developmental State Paper Presented at the Conference on 'Globalisation and Economic Security in East Asia: Governance and Institutions', 11-12 September, 2003, Institute of Defence and Strategic Studies, Nanyang Technological University, Singapore.pp 7-10

${ }^{15}$ Cit Op n 15

${ }^{16}$ Rhys Jenkins Transnational Corporations and Uneven Development in the third world pp 131-136.

${ }^{17}$ Steve Forbes (2015)

${ }^{18}$ Cit op p 1

${ }^{19}$ Rhys Jenkins Transnational Corporations and Uneven Development in the third world pp 131-136

${ }^{20}$ Scott Ian. [1989] (1989) Political Change and the Crisis of Legitimacy in Hong Kong. University of Hawaii Press pp 100112

${ }^{21}$ ibid p100

22 J. F. Ermisch and W. G. Huff, "Hypergrowth in an East Asian NIC: Public Policy and Capital Accumulation in Singapore", World Development Vol. 27 No. 1, 1999, p21. 
corporations. Many of these governments were noticing how these once poor nations were expanding into industries other than manufacturing such as the financial sector ${ }^{23}$.

During the 1980's and 1990s Australia responded by removing tariff controls and also moving away from a centralized industrial relations system to enterprise bargaining. This change of policy led to a closer convergence of wages paid to workers in the first world compared to Singapore and Hong Kong. Even to this day Australian wages are still higher but the gap has narrowed considerably ${ }^{24}$.

Singapore and Hong Kong ultimately succeeded in having an open economy without tariff barriers or strong industrial relations. Their strategy was to entice the transnational corporations with subsidized cheap labor and very low taxes whilst at the same time a government department would develop infant industries that would expand in their operation over a period of time ${ }^{25}$. Many of these industries were supported by government grants and funding. Once these countries had developed their own manufacturing industries they would expand into other sectors such as finance sector. This has been the case with both Singapore and Hong Kong who are no longer involved in low skilled manufacturing of goods because it is cheaper to go China or any other country which has a cheap pool of labour ${ }^{26}$. The first world nations are still seeking to reduce the cost of doing business by limiting the growth of wages and controlling the bargaining power of trade unions. However, the gap is narrowing between the first world and the third world. One consequence is that as the price of labour must be cheaper for the transnational corporations to maximize profits ${ }^{27}$; this has the potential to cause transnationals to source products from dubious operators, who may use forced labour to manufacture goods. This will only increase in the future as corporations seek to increase profits.

\section{The New Wave of Industrialisation}

Today transnational corporations have moved to Bangladesh and Myanmar where labour is cheaper than before than ever before. The paper will now consider Bangladesh and Myanmar and how these countries have been used by corporations to make a quick profit. Both countries have been in economic turmoil for many years and, unless there is a massive turn around, it is unlikely that both nations will ever be like other nations who used this strategy to make their countries into economic powerhouses.

Both of these countries had dictatorships and were under military rule for a certain period of time. They have both experienced severe poverty. Another issue is that both countries lack governments which have the entrepreneurial skills of Singapore and Hong Kong. In addition, Bangladesh and Myanmar are considered very corrupt by world standards ${ }^{28}$ Working conditions are very bad with poor ventilation, and very little pay which can be as low as $\$ 20$ for 19 hours of work.

During the early 2007 Bangladesh began to establish itself as a manufacturing hub for textiles and clothing with all the international fashion labels throughout the world but was heavily dependent on forced labour. Companies included Marks \& Spencer, Nike, Walmart Gap and Victoria Secret have used forced labour in Bangladesh ${ }^{29}$. For example, Nike in the 1990's was caught by consumer rights groups using child labour. Nick has long been strong advocate for workers' rights and now claims that it has an ethical policy of not using forced labour. In an interview, asked if Nike still uses forced labour, Nike CEO 'Todd McKean admitted that the company's attitude was "we don't own the factories, we don't control what goes on in there."

\footnotetext{
${ }^{23}$ Garry Rodan, Singapore's 'second industrial revolution': State intervention and foreign investment, ASEAN Australia Economic Papers No. 18, 1985, pp14- 35.

${ }^{24}$ Gary Bank (2004) 'Structural reforms Australian style: lessons learnt for others, Australian Productivity Commission: pp $1-38$

${ }^{25}$ Ibid p 6

${ }^{26}$ Cit op n 25 p 15

${ }^{27}$ ECD Glossary of Statistical Terms - Wages and salaries - SNA definition". OECD. July 19, 2002

${ }^{28} \mathrm{http}: / /$ news.bbc.co.uk/2/hi/south_asia/4353334.stm and also see

29 David MacIntyre (2014), '10 Major Clothing Brands Caught in Shocking Sweatshop Scandals: http://www.therichest.com/rich-list/most-shocking/10-major-clothing-brands-caught-in-shocking-sweatshopscandals/?view=all
} 
Likewise Walmart, denied any involvement in manufacturing clothing using forced labour in Bangladesh as this would be against the ethical rules that the company espouses. However, it was later discovered that clothing for the company was produced in Bangladesh where they were only paying \$20 per month per employee for a 19 hour shift. ${ }^{30}$ In 2012 a fire started at Tazreen Fashion factory which employed 1630 employee in a very small factory with poor ventilation and fire escapes. During the fire the owners left the workers trapped in the poorly maintained building. At least 117 were killed and 200 serious injured ${ }^{31}$. The publicity from the fire caused the corporations to move to Myanmar where wages are cheaper and human exploitation is far worse than Bangladesh.

As one can see Bangladesh and Myanmar have no chance of using transnational corporations to improve their living standards as has been the case in Singapore or Hong Kong. Bangladesh is an example of the new wave of industrialization where the company and its consumers live in another part of the world. When their goods are made by a third party it is difficult to trace links back to the fashion labels. It also an environment where the pay and working conditions are poor and workers die. There are no ready solutions. Today, with 21 million people being exploited though being put into forced labour, the UN and ILO need to revisit the decision of the 1970s, i.e. for the ILO to reverse the decision not link Human Rights to workers' rights. Unless this is done, more of the world's poor will find themselves in poverty and being exploited and placed into force labour.

Only with exposure of the conditions of their operations, as was the case of Bangladesh, will transnational organizations change their operations. Alternatively, they face the consequences of consumer boycotting their goods which will affect their ability to maximize their profit.

\footnotetext{
${ }^{30}$ Farid Ahmed (25 November 2012). "At least 117 killed in fire at Bangladeshi clothing factory". CNN. Archived from the original on 25 November 2012. Retrieved 25 November 2012.bid

31 ibid
} 
